\title{
Devosia geojensis sp. nov., isolated from diesel-contaminated soil in Korea
}

\author{
Seung Hyun Ryu, ${ }^{1}$ Bok Sil Chung, ${ }^{1}$ Ngoc Thuan Le, ${ }^{1}$ Ho Hee Jang, ${ }^{1}$ \\ Pil-Yong Yun, ${ }^{2}$ Woojun Park ${ }^{3}$ and Che Ok Jeon ${ }^{1}$ \\ ${ }^{1}$ Division of Applied Life Science, EB-NCRC, PMBBRC, Gyeongsang National University, \\ Jinju 660-701, Republic of Korea \\ ${ }^{2}$ Jeju Hi-Tech Industry Development Institute, 4-8 Ara-1 dong, Jeju 690-121, Republic of Korea \\ ${ }^{3}$ Division of Environmental Science and Ecological Engineering, Korea University, Seoul 136-701, \\ Republic of Korea
}

Correspondence

Che Ok Jeon

cojeon@gnu.ac.kr
The genus Devosia (family Hyphomicrobiaceae, order Rhizobiales, class Alphaproteobacteria) was first described by Nakagawa et al. (1996) with the transfer of 'Pseudomonas riboflavina' (Foster, 1944) to Devosia riboflavina. At the time of writing, the genus comprises six species: Devosia riboflavina (Nakagawa et al., 1996), D. neptuniae (Rivas et al., 2003), D. limi (Vanparys et al., 2005), D. soli (Yoo et al., 2006), D. insulae (Yoon et al., 2007) and D. subaequoris (Lee, 2007). In the course of the screening of micro-organisms from contaminated soil, we isolated a novel bacterium, designated strain $\mathrm{BD}-\mathrm{c} 194^{\mathrm{T}}$, belonging to the genus Devosia. Here we describe the polyphasic analysis used to determine its taxonomic position.

Diesel-contaminated soil was collected from the dieselcontaminated soil surface of a gas (petrol) station on Geoje Island, Korea. The total petroleum hydrocarbon content of the contaminated soil was about $2000 \mathrm{mg} \mathrm{kg}^{-1}$. The soil

The GenBank/EMBL/DDBJ accession number for the 16S rRNA gene sequence of strain $\mathrm{BD}-\mathrm{c} 194^{\top}$ is EF575560.

A transmission electron micrograph of negatively stained cells of strain BD-c194 and a table comparing the cellular fatty acid compositions of strain BD-c194 ${ }^{\top}$ and type strains of related Devosia species are available as supplementary material with the online version of this paper. sample was serially diluted with a $1 \%(\mathrm{w} / \mathrm{v})$ saline solution and spread on R2A agar (Difco). After 5 days incubation at $25^{\circ} \mathrm{C}$, strain BD-c194 ${ }^{\mathrm{T}}$ was selected from an agar plate and analysed. Although strain BD-c194 ${ }^{\mathrm{T}}$ was isolated from dieselcontaminated soil, it did not grow on minimal agar medium (Stanier et al., 1966) containing diesel as the sole carbon and energy source, showing that the strain is not a diesel degrader.

The morphological, physiological and biochemical characteristics of strain $\mathrm{BD}-\mathrm{c} 194^{\mathrm{T}}$ were examined using routine cultivation on $\mathrm{R} 2 \mathrm{~A}$ medium at $30{ }^{\circ} \mathrm{C}$ for 3 days (except where indicated otherwise). The type strains of some related taxa (see Table 1) were used as reference strains for the biochemical tests.

The temperatures and $\mathrm{pH}$ for growth of strain BD-c194 ${ }^{\mathrm{T}}$ were investigated by growing the isolate on $\mathrm{R} 2 \mathrm{~A}$ agar at different temperatures $\left(5-50{ }^{\circ} \mathrm{C}\right.$, in $5{ }^{\circ} \mathrm{C}$ increments) and in $\mathrm{R} 2 \mathrm{~A}$ broth adjusted to different $\mathrm{pH}$ values $(\mathrm{pH}$ 5.0-10.0, in increments of $0.5 \mathrm{pH}$ units) (Gomori, 1955). Gram staining was performed using a bioMérieux Gram Stain kit according to the instructions of the manufacturer. Oxidase activity was tested by assessing the oxidation of $1 \%(\mathrm{w} / \mathrm{v})$ tetramethyl-p-phenylenediamine (Merck); catalase activity 
Table 1. Differential physiological and biochemical characteristics of strain BD-c194 ${ }^{\top}$ and type strains of related Devosia species

Strains: 1, BD-c194 ${ }^{\mathrm{T}} ; 2$, D. insulae DS-56 ${ }^{\mathrm{T}}$; 3, D. riboflavina IFO $13584^{\mathrm{T}} ;$ 4, D. neptuniae LMG $21357^{\mathrm{T}}$; 5, D. limi ${\mathrm{LMG} 22951^{\mathrm{T}} \text {; 6, D. soli GH2-10 }}^{\mathrm{T}}$. Data were obtained in this study unless indicated. All strains were Gram-negative, aerobic, non-spore-forming and positive for catalase. In the API $20 \mathrm{NE}$ and API ZYM test strips, all strains were positive for aesculin hydrolysis and for leucine arylamidase and $\beta$-glucosidase activities. All strains were negative for lipase (C14), cystine arylamidase, $\alpha$-chymotrypsin and $\beta$-glucuronidase activities, indole production, nitrate reduction and the assimilation of caprate, adipate, malate, citrate and phenyl acetate. +, Positive; w, weakly positive; -, negative; NA, data not available.

\begin{tabular}{|c|c|c|c|c|c|c|}
\hline Characteristic & 1 & 2 & 3 & 4 & 5 & 6 \\
\hline Motility & + & $+^{a}$ & $+{ }^{b}$ & $+^{c}$ & $-{ }^{d}$ & NA \\
\hline Oxidase & + & - & + & + & + & - \\
\hline Urease & + & + & - & - & - & + \\
\hline Starch & - & - & + & - & - & + \\
\hline L-Tyrosine & + & - & - & - & + & - \\
\hline \multicolumn{7}{|l|}{ Enzyme activities } \\
\hline Alkaline phosphatase & $\mathrm{W}$ & - & + & + & + & + \\
\hline Esterase $(\mathrm{C} 4)$ & + & + & + & - & + & + \\
\hline Esterase lipase (C8) & $\mathrm{w}$ & + & + & - & + & + \\
\hline$\alpha$-Mannosidase & - & - & + & + & - & + \\
\hline$\alpha$-Fucosidase & - & + & + & + & - & - \\
\hline \multicolumn{7}{|l|}{ Assimilation of: } \\
\hline D-Glucose, D-mannose, D-mannitol, maltose & + & - & + & + & - & - \\
\hline L-Arabinose & - & - & + & + & - & - \\
\hline$N$-Acetylglucosamine & + & - & + & - & - & - \\
\hline DNA G $+\mathrm{C}$ content $(\mathrm{mol} \%)$ & 60.8 & $66.2^{a}$ & $61.4^{b}$ & $62.0^{c}$ & $61.9^{d}$ & $59.5^{e}$ \\
\hline
\end{tabular}

${ }^{\star}$ Data taken from: $a$, Yoon et al., 2007; b, Nakagawa et al., 1996; c, Rivas et al., 2003; d, Vanparys et al., 2005; e, Yoo et al., 2006.

$\nmid \mathrm{C}$, Cream; I, ivory; LBE, light beige; LBR, light brown; LY, light yellow; PWH, pearl white; wH, white.

was evaluated by determining the production of oxygen bubbles in a $3 \%(\mathrm{v} / \mathrm{v})$ aqueous hydrogen peroxide solution. Cell morphology and motility were studied using phase-contrast microscopy and transmission electron microscopy (JEM-1010; JEOL) at different growth stages, as described by Jeon et al. (2005). Hydrolysis of casein, gelatin, Tween 80 , Tween 20 , aesculin, urea, tyrosine and starch was investigated on R2A agar after 7 days incubation, as described previously (Lanyi, 1987; Smibert \& Krieg, 1994). Nitrate reduction was investigated according to the method of Lanyi (1987) and acid production from carbohydrates was tested as described by Leifson (1963). Additional enzyme activities and biochemical features were determined using API ZYM and API 20NE kits at $30{ }^{\circ} \mathrm{C}$ as recommended by the manufacturer (bioMérieux). Antibiotic-susceptibility tests were performed in duplicate using filter-paper discs (diameter, $8 \mathrm{~mm}$ ) on R2A agar containing the following antibiotics: ampicillin $(10 \mu \mathrm{g})$, polymyxin B (100 U), streptomycin $(50 \mu \mathrm{g})$, penicillin $\mathrm{G}$ (10 IU), chloramphenicol $(100 \mu \mathrm{g})$, gentamicin $(30 \mu \mathrm{g})$, tetracycline $(30 \mu \mathrm{g})$, kanamycin $(30 \mu \mathrm{g})$, lincomycin
$(15 \mu \mathrm{g})$, oleandomycin $(15 \mu \mathrm{g})$, neomycin $(30 \mu \mathrm{g})$, carbenicillin $(100 \mu \mathrm{g})$ and novobiocin $(50 \mu \mathrm{g})$.

Growth of strain BD-c194 $194^{\mathrm{T}}$ was observed at temperatures between 15 and $45{ }^{\circ} \mathrm{C}$, with an optimum at $30-35{ }^{\circ} \mathrm{C}$. The strain grew at $\mathrm{pH}$ 6.0-9.5, with an optimum at $\mathrm{pH}$ 7.5-9.0. All of the cells that were observed were rods $(0.5-0.8 \mu \mathrm{m}$ wide and 1.0-2.0 $\mu \mathrm{m}$ long), motile by means of single polar flagella (Supplementary Fig. S1, available in IJSEM Online). Anaerobic growth was not observed after 10 days incubation at $30{ }^{\circ} \mathrm{C}$ on R2A agar. Other phenotypic features of strain $\mathrm{BD}-\mathrm{c} 194^{\mathrm{T}}$ are listed in the description of the novel species.

For the analysis of fatty acid methyl esters, cells of strain $\mathrm{BD}-\mathrm{c} 194^{\mathrm{T}}$ and reference strains were harvested from agar plates after 3 days incubation on trypticase soy agar (TSA; Difco) at $25{ }^{\circ} \mathrm{C}$. Analysis of the fatty acid methyl esters was performed according to the instructions of the Microbial Identification System (MIDI; Microbial ID). Analysis of isoprenoid quinones and polar lipids was carried out using the methods described by Komagata \& Suzuki (1987). The 
DNA $G+C$ content of strain BD-c194 ${ }^{\mathrm{T}}$ was determined using an HPLC apparatus fitted with a reversed-phase column (GROM-SIL 100 ODS-2FE; GROM) according to the method of Tamaoka \& Komagata (1984). The major cellular fatty acids of strain $\mathrm{BD}-\mathrm{c} 194^{\mathrm{T}}$ were $\mathrm{C}_{16: 0}(32.02 \%)$, 11-methyl $\mathrm{C}_{18: 1} \omega 7 c(26.47 \%)$ and $\mathrm{C}_{18: 0}(14.42 \%)$; this profile is similar to those of related type strains of members of the genus Devosia (Supplementary Table S1). The predominant polar lipid was phosphatidylglycerol, but a small amount of diphosphatidylglycerol was also present. The major respiratory lipoquinone of strain $\mathrm{BD}-\mathrm{c} 194^{\mathrm{T}}$ was Q-10. The DNA G $+\mathrm{C}$ content of strain $\mathrm{BD}-\mathrm{c} 194^{\mathrm{T}}$ was $60.8 \mathrm{~mol} \%$. The major fatty acids, major lipoquinone and polar lipids and DNA $\mathrm{G}+\mathrm{C}$ content are in accordance with those of members of the genus Devosia (Nakagawa et al., 1996; Rivas et al., 2003; Vanparys et al., 2005; Yoo et al., 2006). A comparison of the typical phenotypic and chemotaxonomic properties of strain BD-c194 ${ }^{\mathrm{T}}$ with those of phylogenetically related relatives is shown in Table 1 . Some of properties are similar to those of members of the genus Devosia, whereas others serve to differentiate strain $\mathrm{BD}-\mathrm{c} 194^{\mathrm{T}}$ from closely related Devosia species.

Sequencing and assembly of the 16S rRNA gene were carried out as described previously (Lane, 1991). The resultant 16S rRNA gene sequence (1449 nt) of strain BD$\mathrm{c} 194^{\mathrm{T}}$ was compared with $16 \mathrm{~S}$ rRNA gene sequences available from GenBank by using the BLAST program (http://www.ncbi.nlm.nih.gov/BLAST/) to determine an approximate phylogenetic affiliation, and the gene sequence was then aligned with those of closely related species by using the CLUSTAL W software program (Thompson et al., 1994). Phylogenetic trees were constructed using three different methods, the neighbour-joining, maximum-likelihood and maximum-parsimony algorithms, available in PHYLIP version
3.6 (Felsenstein, 2002). Values for sequence similarity between the isolate and related members of the genus Devosia were computed using SIMILARITY MATRIX version 1.1 (Ribosomal Database Project II; http://35.8.164.52/html/) (Cole et al., 2003). A bootstrap analysis was performed according to the algorithm of Kimura's two-parameter model (Kimura, 1980) of the neighbour-joining method in the PHYLIP package. Phylogenetic analysis based on 16S rRNA gene sequences indicated that strain $\mathrm{BD}-\mathrm{c} 194^{\mathrm{T}}$ formed a welldefined phyletic lineage within the genus Devosia (with $100 \%$ bootstrap support) (Fig. 1). The overall topology of the neighbour-joining tree was supported by the topologies of the trees built using the maximum-likelihood and maximum-parsimony algorithms (Fig. 1). A comparative $16 \mathrm{~S}$ rRNA gene sequence analysis showed that the isolate was most closely related to $D$. insulae DS- $56^{\mathrm{T}}, D$. neptuniae LMG $21357^{\mathrm{T}}$, D. riboflavina IFO $13584^{\mathrm{T}}, D$. limi LMG $22951^{\mathrm{T}}$ and D. soli KACC $11509^{\mathrm{T}}$, with similarities of $96.1,95.7,95.4,95.1$ and $95.0 \%$, respectively; these levels of similarity conform to the criteria for classification as different species in the same genus (Rosselló-Mora \& Amann, 2001; Stackebrandt et al., 2002). Therefore, the physiological, biochemical and phylogenetic properties of strain $\mathrm{BD}-\mathrm{c} 194^{\mathrm{T}}$ support its description as a novel species within the genus Devosia, for which the name Devosia geojensis sp. nov. is proposed.

\section{Description of Devosia geojensis sp. nov.}

Devosia geojensis (geo.jen'sis. N.L. fem. adj. geojensis pertaining to Geoje in Korea, the location of the soil sample from which the type strain was isolated).

Colonies are white, raised and circular with entire margins after 3 days on R2A agar. Cells are strictly aerobic, Gramnegative, short, motile rods (about $0.5-0.8 \mu \mathrm{m}$ wide and

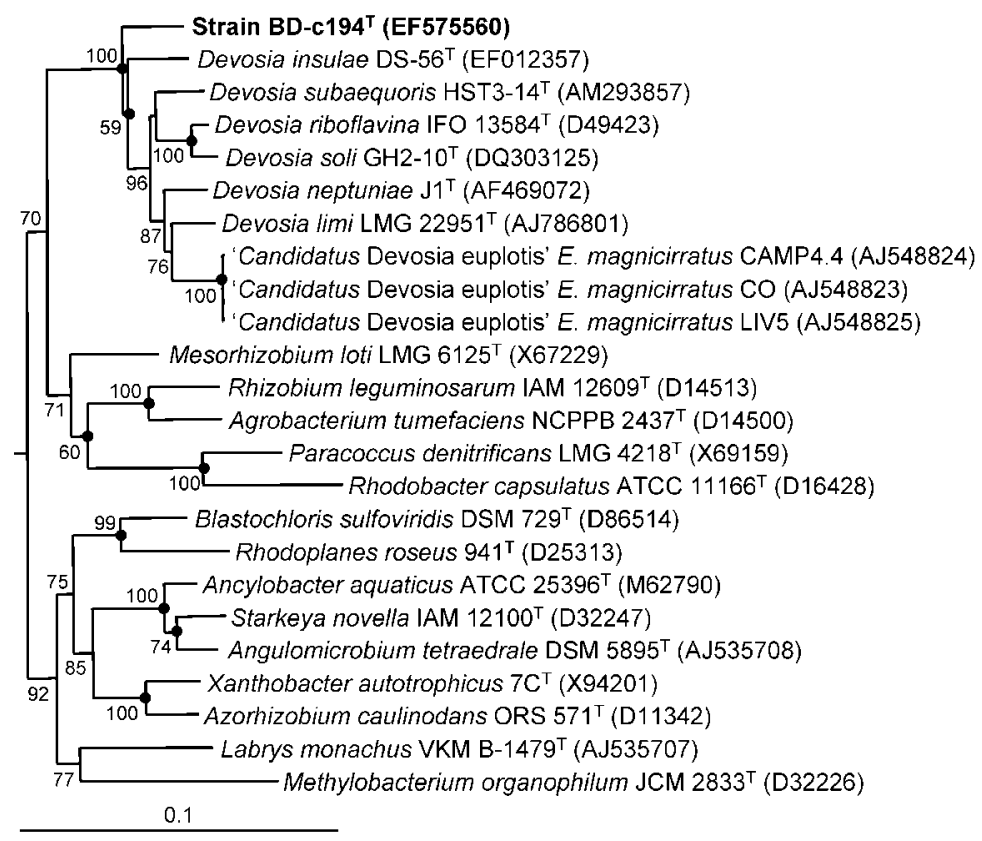

Fig. 1. Neighbour-joining phylogenetic tree, based on 16S rRNA gene sequences, showing the relationships of strain BD-c194 ${ }^{\top}$ and related taxa. Bootstrap percentages (based on 1000 replicates) greater than $50 \%$ are shown at branch points. Filled circles indicate that the corresponding nodes were also recovered in trees generated with the maximum-likelihood and maximum-parsimony algorithms. Escherichia coli ATCC $11775^{\top}$ (GenBank accession no. X80725) was used as an outgroup (not shown). Bar, 0.1 changes per nucleotide position. 
1.0-2.0 $\mu \mathrm{m}$ long) with single polar flagella. Growth occurs optimally at $30-35{ }^{\circ} \mathrm{C}$ and $\mathrm{pH} 7.5-9.0$. Catalase- and oxidase-positive. Nitrate is not reduced to nitrite. Aesculin, urea and L-tyrosine are hydrolysed, but casein, Tween 80, Tween 20, gelatin and starch are not. Produces acid from raffinose, myo-inositol, D-mannose, D-glucose, D-fructose, D-mannitol, L-arabinose, melibiose, lactose, arbutin and salicin, but not from D-galactose. Negative for indole production, D-glucose fermentation and arginine dihydrolase activity. Positive for assimilation of D-glucose, D-mannose, D-mannitol, $\mathrm{N}$-acetylglucosamine and maltose, but negative for assimilation of L-arabinose, potassium gluconate, capric acid, adipic acid, malic acid, trisodium citrate and phenylacetic acid (API 20NE). Produces esterase (C4) and leucine arylamidase, but not lipase (C14), cystine arylamidase, $\alpha$-chymotrypsin, $\alpha$-galactosidase, $\beta$-glucuronidase, $\alpha$-mannosidase and $\alpha$-fucosidase. Weak enzyme activities are observed for alkaline phosphatase, esterase lipase (C8), $\alpha$-glucosidase, $\beta$-glucosidase and $N$-acetyl- $\beta$-glucosaminidase, valine arylamidase, trypsin, acid phosphatase, naphthol-AS-BI-phosphohydrolase and $\beta$-galactosidase. Resistant to chloramphenicol, polymyxin B, streptomycin, gentamicin, kanamycin, novobiocin, oleandomycin, neomycin and lincomycin, but sensitive to ampicillin, penicillin G, tetracycline and carbenicillin. Contains a large amount of phosphatidylglycerol and a small amount of diphosphatidylglycerol as the polar lipids. The major isoprenoid quinone is Q-10. The major cellular fatty acids are 11-methyl $\mathrm{C}_{18: 1} \omega 7 c, \mathrm{C}_{16: 0}$ and $\mathrm{C}_{18: 0}$. The DNA $\mathrm{G}+\mathrm{C}$ content of the type strain is $60.8 \mathrm{~mol} \%$ (HPLC).

The type strain, BD-c194 ${ }^{\mathrm{T}}\left(=\mathrm{KCTC} 22082^{\mathrm{T}}=\mathrm{DSM}\right.$ $\left.19414^{\mathrm{T}}\right)$, was isolated from diesel-contaminated soil from Geoje, Korea.

\section{Acknowledgements}

These efforts were supported by grants from MOST/KOSEF to the Environmental Biotechnology National Core Research Center (grant R15-2003-012-02002-0) and from the BioGreen 21 Program (code 20070301034002) of the Rural Development Administration, Republic of Korea. S. H. R. and N. T. L. were supported by scholarships from the BK21 program of the Ministry of Education and Human Resources Development in Korea.

\section{References}

Cole, J. R., Chai, B., Marsh, T. L., Farris, R. J., Wang, Q., Kulam, S. A., Chandra, S., McGarrell, D. M., Schmidt, T. M. \& other authors (2003). The Ribosomal Database Project (RDP-II): previewing a new autoaligner that allows regular updates and the new prokaryotic taxonomy. Nucleic Acids Res 31, 442-443.

Felsenstein, J. (2002). PHYLIP (phylogeny inference package), version 3.6a. Distributed by the author. Department of Genome Sciences, University of Washington, Seattle, USA.

Foster, J. W. (1944). Microbiological aspects of riboflavin. I. Introduction. II. Bacterial oxidation of riboflavin to lumochrome. J Bacteriol 47, 27-41.
Gomori, G. (1955). Preparation of buffers for use in enzyme studies. Methods Enzymol 1, 138-146.

Jeon, C. O., Lim, J. M., Lee, J. M., Xu, L. H., Jiang, C. L. \& Kim, C. J. (2005). Reclassification of Bacillus haloalkaliphilus Fritze 1996 as Alkalibacillus haloalkaliphilus gen. nov., comb. nov. and the description of Alkalibacillus salilacus sp. nov., a novel halophilic bacterium isolated from a salt lake in China. Int J Syst Evol Microbiol 55, 1891-1896.

Kimura, M. (1980). A simple method for estimating evolutionary rates of base substitutions through comparative studies of nucleotide sequences. J Mol Evol 16, 111-120.

Komagata, K. \& Suzuki, K. (1987). Lipid and cell-wall analysis in bacterial systematics. Methods Microbiol 19, 161-207.

Lane, D. J. (1991). 16S/23S rRNA sequencing. In Nucleic Acid Techniques in Bacterial Systematics, pp. 115-175. Edited by E. Stackebrandt \& M. Goodfellow. Chichester: Wiley.

Lanyi, B. (1987). Classical and rapid identification methods for medically important bacteria. Methods Microbiol 19, 1-67.

Lee, S. D. (2007). Devosia subaequoris sp. nov., isolated from beach sediment. Int J Syst Evol Microbiol 57, 2212-2215.

Leifson, E. (1963). Determination of carbohydrate metabolism of marine bacteria. J Bacteriol 85, 1183-1184.

Nakagawa, Y., Sakane, T. \& Yokota, A. (1996). Transfer of "Pseudomonas riboflavina" (Foster 1944), a gram-negative, motile rod with long-chain 3-hydroxy fatty acids, to Devosia riboflavina gen. nov., sp. nov., nom. rev. Int J Syst Bacteriol 46, 16-22.

Rivas, R., Willems, A., Subba-Rao, N. S., Mateos, P. F., Dazzo, F. B., Kroppenstedt, R. M., Martínez-Molina, E., Gillis, M. \& Velázquez, E. (2003). Description of Devosia neptuniae sp. nov. that nodulates and fixes nitrogen in symbiosis with Neptunia natans, an aquatic legume from India. Syst Appl Microbiol 26, 47-53.

Rosselló-Mora, R. \& Amann, R. (2001). The species concept for prokaryotes. FEMS Microbiol Rev 25, 39-67.

Smibert, R. M. \& Krieg, N. R. (1994). Phenotypic characterization. In Methods for General and Molecular Bacteriology, pp. 607-654. Edited by P. Gerhardt, R. G. E. Murray, W. A. Wood \& N. R. Krieg. Washington, DC: American Society for Microbiology.

Stackebrandt, E., Frederiksen, W., Garrity, G. M., Grimont, P. A. D., Kämpfer, P., Maiden, M. C. J., Nesme, X., Rosselló-Mora, R., Swings, J. $\&$ other authors (2002). Report of the ad hoc committee for the reevaluation of the species definition in bacteriology. Int J Syst Evol Microbiol 52, 1043-1047.

Stanier, R. Y., Palleroni, N. J. \& Doudoroff, M. (1966). The aerobic pseudomonads: a taxonomic study. J Gen Microbiol 43, 159-271.

Tamaoka, J. \& Komagata, K. (1984). Determination of DNA base composition by reversed-phase high-performance liquid chromatography. FEMS Microbiol Lett 25, 125-128.

Thompson, J. D., Higgins, D. G. \& Gibson, T. J. (1994). ClustaL W: improving the sensitivity of progressive multiple sequence alignment through sequence weighting, position-specific gap penalties and weight matrix choice. Nucleic Acids Res 22, 4673-4680.

Vanparys, B., Heylen, K., Lebbe, L. \& De Vos, P. (2005). Devosia limi sp. nov., isolated from a nitrifying inoculum. Int J Syst Evol Microbiol 55, 1997-2000.

Yoo, S.-H., Weon, H. Y., Kim, B. Y., Hong, S.-B., Kwon, S.-W., Cho, Y.-H., Go, S.-J. \& Stackebrandt, E. (2006). Devosia soli sp. nov., isolated from greenhouse soil in Korea. Int J Syst Evol Microbiol 56, 2689-2692.

Yoon, J.-H., Kang, S.-J., Park, S. \& Oh, T.-K. (2007). Devosia insulae sp. nov., isolated from soil, and emended description of the genus Devosia. Int J Syst Evol Microbiol 57, 1310-1314. 